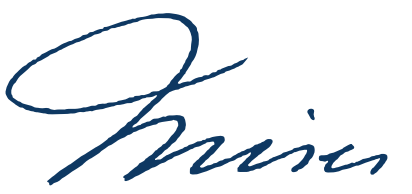

\title{
The Biblical Ethic of Free Market Exchange
}

\author{
Jeffery Degner ID 0000-0003-1556-5197
}

Cornerstone University - Grand Rapids - MI - United States

\begin{abstract}
Despite the calls of 'Christian Socialists' to bring market forces under state control and its temporal power, the Bible supports free markets. It also prescribes their existence and operation as the standard, God-given means of social interaction. Both the Old and New Testaments provide an ethical defense of the market itself, the division of labor, and the principle of voluntary exchange, condemning force, fraud, and coercion. As the introduction of force into society and exchange is always and ever the policy of interventionists and socialists, this paper aims to oppose those doctrines on the grounds of Biblical ethics. The dismantling of socialism on pragmatic, historic, or epistemological grounds has been thorough and devastating as provided by the Austrian school of economics. This work provides a moral and ethical ground that not only dismisses the socialist agenda, but adds to an already robust body of work that rejects its interventions due to its inefficiencies, failed states, and its pretense of knowledge.
\end{abstract}

Keywords: Ethics, Religion, Free Markets.

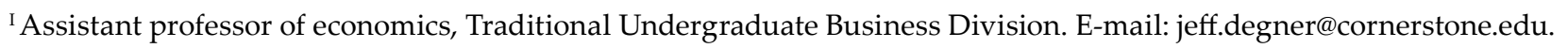




\section{La ética bíblica del intercambio del libre mercado}

Resumen: A pesar de los pedidos de los 'socialcristianos' de poner las fuerzas del mercado bajo el control del estado y su poder temporal, la Bíblia defiende los libres mercados. Además, prescribe su existencia y funcionamiento como los medios normales, otorgados por Dios, de interacción social. Tanto el Antiguo como el Nuevo Testamento de la Biblia proporcionan una defensa ética del mercado en sí mismo, la división del trabajo, el principio del intercambio voluntario y la condena a la fuerza, el fraude y la coacción. Como la presentación de la fuerza en la sociedad y el intercambio ha sido siempre la política de intervencionistas y socialistas, ese ensayo busca oponerse a esas doctrinas sobre la base de la ética bíblica. El desmantelamiento del socialismo en bases pragmáticas, históricas y epistemológicas, por parte de la Escuela Austríaca, fue devastador. Este trabajo proporciona un fundamento moral y ético que no solo descarta la agenda socialista, sino que se suma a un cuerpo de trabajo que ya es sólido y que rechaza sus intervenciones debido a sus ineficiencias, estados fallidos y su pretensión de conocimiento.

Palabras-chaves: Ética, religión, Libre Mercado.

\section{A ética bíblica das trocas no livre mercado}

Resumo: Apesar dos pedidos dos "cristãos socialistas" de submeter as forças do mercado ao controle do Estado e seu poder temporal, a Bíblia defende o livre mercado. Além disso, prescreve sua existência e operação como os meios normais, outorgados por Deus, de interação social. Tanto o Antigo como o Novo Testamentos fornecem uma defesa ética do mercado, da divisão do trabalho e do princípio da troca voluntária, condenando a força, a fraude e a coerção. Como a introdução da força na sociedade e nas trocas sempre foi a política de intervencionistas e socialistas, esse artigo busca se opor a essas doutrinas, com base na ética bíblica. O desmantelamento do socialismo em bases pragmáticas, históricas e epistemológicas por parte da Escola Austríaca foi devastador. Esse artigo proporciona uma base moral e ética que não só descarta a agenda socialista, mas que se soma a um corpo de trabalho robusto que rejeita suas intervenções devido as suas ineficiências, estados falidos e sua pretensão de conhecimento.

Palavras-chaves: Ética, religião, Livre Mercado. 


\section{Introduction}

This paper aims to demonstrate that the Bible not only describes the free market, but it also reveals the ethical standards for its operation, providing the everyday means for human flourishing. By using the Scripture's moral guidance, we do not dismiss Mises' argument that "all moral rules and human laws are means for the realization of definite ends. There is no method available for the appreciation of their goodness or badness other than to scrutinize their usefulness for the attainment of the ends chosen and aimed at" (MISES, 2008). There is no dispute that morals are means. Besides, we may evaluate the goodness of these moral codes based on their outcomes in terms of human flourishing. However, assuming the divine inspiration of morals in no way cancels the claim that these moral codes are means to desirable ends.

Although Mises' argument is circular, proving that a moral code is good because it produces desired ends, and that its fulfillment results from applying a good moral rule, this in no way invalidates his claim. Our argument is also circular. We claim that moral practices in the market generate peace and prosperity, and that these ends are achieved through moral means. The fact that both arguments are circular does not disprove either of them. Our claim is not entirely different from Mises' when he states that "the notion of right and wrong is...a utilitarian precept designed to make social cooperation under the division of labor possible" (MISES, 2008, p. 716). This paper contends that the notion of right and wrong is divinely revealed and designed to make social cooperation under the division of labor possible. Mises' hostility to natural law as a foundation for determining what is good would undoubtedly apply to the notion of divine law. However, his student Murray Rothbard was a proponent of natural law as a source for morality. We move one step beyond Rothbard in claiming that the "perennial standard of what is just and what is unjust" (MISES, 2008, p. 716) is, in fact, a mistaken notion. If morality is not perennial as Mises claims, then there can be no claim that voluntary exchange is just, as it is a means not subject to iron-clad, permanent morality.

Furthermore, we are more inclined to agree with Rothbard's assertion that this natural law, which is shared by human reason, "can spread only through peaceful persuasion, and that the use of force can only erode and impair morality" (ROTHBARD, 2009). We contend that morality is spread peacefully by God and His properly behaving servants. The Bible not only describes free enterprise and peaceful persuasion as the moral means for achieving human flourishing, but it also provides the specific moral actions which best produce social coordination, peace, and prosperity. Finally, we will show that both Testaments describe the righteous and just response to genuinely free market outcomes, which socialists respond to with violence, force, and coercion.

The reader will quickly recognize our emphasis on a Biblical exposition of passages related to market behavior. After having discussed both Mises' and Rothbard's views on morality in the marketplace, we will show that even though Mises might dismiss perennial law, and Rothbard generally adopts natural law to justify voluntary exchange as the means to attain human flourishing, the Bible ultimately agrees with them, namely, that voluntary exchange, free from the interference of fraud, force or coercion, is the only path towards human flourishing. 
This paper may not convince the reader who firmly holds to either Mises' or Rothbard's position to adopt a divinely-inspired view of morality. However, they should find it valuable as yet another validation of free-market exchange, coming from a theological viewpoint. This additional argument provides a further justification for claiming that voluntary exchange is moral because it works to achieve ends, besides being consistent with human reason, natural law, and the divine character described in the Bible.

Our objective is to demonstrate the following:

1. The Bible describes voluntary exchange as the practical and moral means to achieve peace, prosperity, and human flourishing.

2. The Bible defines and condemns fraud and force in the marketplace, whether perpetrated by the State, by systems of oppression enshrined by legislation, or by individual acts of deception.

3. The Bible recognizes productive inequality as a righteous and just phenomenon.

Concerning the first principle of voluntary exchange as a means to peace and prosperity, we will focus on two Biblical passages. Proverbs 16:7 states that “When a man's ways please the LORD, He makes even his enemies be at peace with him." Secondly, to show how the Bible affirms free and voluntary exchange, we will refer to the early Church's actions, recorded in Acts chapters 2-5. We should note that this very passage is often used by those calling themselves 'Christian socialists' as the Biblical endorsement of state-enforced redistribution schemes. Instead, as we will see, this passage supports and exalts the principles of private property, voluntary exchange, and cheerful giving with integrity.

As for the second proposition, the Scripture' definition and condemnation of fraud, we begin with Proverbs 16:11, "A just balance and scales are the LORDS, all the weights in the bag are His work," complemented by Proverbs 11:1, 20:10, and 20:23, in which we are reminded that "Unequal weights and measures are an abomination to the LORD". Furthermore, in Deuteronomy 25:13-16, people are considered detestable for the mere possession of unequal weights, regardless of whether they are used to defraud others. Throughout Christendom, one hears that God hates the sin but loves the sinner: it is not so when it comes to the tools of fraud in the marketplace. God hates BOTH the sin AND the sinner who possesses or uses unequal weights in the market.

Third, Scripture declares that productive inequality is a natural phenomenon. Furthermore, the Kingdom of God not only has unequal outcomes, but God's unequal rewards are also simultaneously just and generous. The parable of the talents demonstrates this clearly in Matthew 25. The story of how not to respond towards God's unequal favor is portrayed in Cain's murder of his brother, Abel, in Genesis chapter 4.

The following paragraphs represent an exposition and commentary on the Scripture and its positions regarding free enterprise. Their focus is to expose the folly of 'Christian socialists' who claim to follow the Word of God, while ignoring its clear and consistent teachings about the righteousness and justice of voluntary exchange. Its tone and style will be familiar to those used to Biblical exposition. Both readers expecting purely economic arguments, and others 
who reject the Bible as God's authoritative Word, viewing it as creative literature created by some enterprising Jewish men, may still take value from this. Whether the traditions of moral principles that defend the free market come from a divine source or conniving men of the cloth, its moral precepts uphold and prescribe free and voluntary exchange as the means to peace and prosperity.

Finally, for those Austro-Libertarians who contend that religion does not provide a basis for the truth claim that free and voluntary exchange is the only moral method of organizing society, they need to be aware that our socialist opponents disagree and, in the words of F.M. Sprague, proclaim that "the claims of Socialism have been tested and approved by reason, religion, and nature" (SPRAGUE, 1892 [emphasis added]). Failing to address the socialists on religious and moral grounds is a dangerous endeavor.

\section{The Bible and Voluntary Exchange}

In Proverbs of Solomon, Chapter 16:7, we are told that:

"When a man's ways please the LORD, He makes even his enemies be at peace with him".

If we desire peace, the follower of Christ needs to please the LORD. This much is clear. Through free-market thinkers, we discover that peace among ourselves results from more than just individual goodwill. The world needs more than love or familial tenderness, more than pious and righteous attitudes. These are necessary, though not sufficient, conditions to foster peace. A world where scarcity is the permanent reality requires something more.

We firmly believe that virtue and righteousness are required for markets to work at their best (SIRICO, 2012). When the State employs certain forms of righteousness, especially its varied and destructive attempts to "cleanse" society, these result in conflict, disorder, and harm to the rest of humanity (LEONARD, 2016).

Where, then, is the proper place to exercise the righteousness that leads to peace in society? Personal righteousness is best employed in the marketplace (KEIL; DELITZSCH, 1982). The apostle Paul was undoubtedly a righteous man, and he faced persecution at the hands of those who hated the messages of the Gospel and the Risen LORD Jesus Christ. Nonetheless, he could interact peacefully with people throughout the Mediterranean world, simply because he was always engaged in commerce as a tent-maker. Through the application of personal righteousness in the marketplace, he could live in peace with those who would otherwise seek his immediate death. Put another way, St. Paul was a living manifestation of Proverbs 16:7.

Despite Paul's example of continually engaging in commercial activity and upholding its principles, so-called "Christian socialists" have openly denied them (GRONLUND, 1890). They consider Paul's call to vigorous productivity as exploitative. At the same time, they misrepresent a brief description of voluntary Christian generosity in the book of Acts as God's endorsement of non-voluntary and state-coerced redistribution. However, as we will demonstrate, the New Testament refers to the voluntary exchange proposed by the early Church and the Apostles, 
not a state-led wealth redistribution system. As Christians acted in righteousness, they applied their efforts to commercial activity. Paul himself said the following in 1 Thessalonians 4 :

9 About brotherly love: You don't need me to write you because you yourselves are taught by God to love one another. 10 In fact, you are doing this toward all the brothers and sisters in the entire region of Macedonia. But we encourage you, brothers and sisters, to do this even more, 11 to seek to lead a quiet life, to mind your own business, and to work with your own hands, as we commanded you, 12 so that you may behave properly in the presence of outsiders and not be dependent on anyone.

Put another way, it is an act of love to lead a quiet life, not being a do-gooding busybody! Bengel notes Paul's use of irony, where the Greek is rendered, "be ambitious to be quiet...to do your own business" (BENGEL, 1858). To leave your neighbors alone exemplifies the nonaggression principle supported by many libertarians in the free-market tradition. Moreover, God commands its people to work, produce, and engage in the market with integrity to avoid dependency. Paul furthers this argument in 1 Thessalonians 5 with a forceful warning towards the idle, and once again in 2 Thessalonians 6, telling Christ's followers that:

We command you, brothers and sisters, in the name of our Lord Jesus Christ, to keep away from every brother or sister who is idle and does not live according to the tradition received from us. 7 For you yourselves know how you should imitate us: We were not idle among you; 8 we did not eat anyone's food free of charge; instead, we labored and toiled, working night and day, so that we would not be a burden to any of you. 9 It is not that we do not have the right to support, but we did it to make ourselves an example to you so that you would imitate us. 10 In fact, when we were with you, this is what we commanded you: "If anyone is not willing to work, he should not eat." 11 For we hear that there are some among you who are idle. They are not busy but busybodies. 12 Now we command and exhort such people by the Lord Jesus Christ to work quietly and provide for themselves. 13 But as for you, brothers and sisters, do not grow weary in doing good. 14 If anyone does not obey our instruction in this letter, take note of that person; do not associate with him, so that he may be ashamed. 15 Yet do not consider him as an enemy, but warn him as a brother.

This passage works as a condensed version of Say's Law. In short, if you wish to exchange for goods and services, you must first produce goods and services of value to others. In other words, it is production that creates wealth, while spending is the exchange of it. By discovering these principles, Say simply describes what happens in the real world (SOWELL, 1972). Moreover, Paul expands on this principle in just one passage by declaring that, by doing so, we release others from burdens. A loving act indeed! Furthermore, the apostle says that productive work not only allows one to exchange goods with integrity, but it also produces peace with would-be enemies (as Proverbs 16:7 contends) through the avoidance of an idle, busybody lifestyle.

Paul's words show that the act of producing in order to exchange is not only good, but the very definition of good works! Paul further expressed in Ephesians 2:10 that God himself has already prepared these types of good works before His people, so that they would follow this path. To put it bluntly, it is a sign of Godliness for Christians to engage in voluntary exchange in a manner that reflects truthfulness, integrity, and good work. This pursuit is 
entirely consistent with the goodness that emerges with voluntary exchange; therefore, it is entirely consistent with the Austrian tradition and its defense of free enterprise.

In Acts Chapters 2-5, we read of the early Church's actions and, in particular, the voluntary and generous actions of its members. As Scripture readers are undoubtedly aware, the so-called 'Christian socialists' equal the sale of property and the laying of those funds at the apostles' feet with the forceful confiscation of wealth by the State as a means of redistributing wealth (ICS, 2020). Two things must be observed in this passage.

First, Peter openly acknowledges that they own believers' property! It is not owned by the Church by virtue of an individual or family joining the Church. Furthermore, these same people who call themselves socialists claim that God is serious about this distribution to the poor, citing that God struck Ananias and Saphira dead because they refused to share. Peter himself says their death was caused by the fact that they LIED, not because they were unwilling to share. Clearly, they were willing to share, although not the full proceeds!

Furthermore, contrary to the redistributionists' assertions, this passage never indicates that the State must take care of the poor. The entire string of events, where believers own property, sell it in the marketplace, presumably at a profit and then voluntarily give it away, is the ultimate example of an organic institution whose followers voluntarily share without a single sign of coercion, threats, or force (MACARTHUR, 1994).

This passage is entirely in accord with the free market and free association position that large group action is perfectly acceptable. It can be peaceful and in line with human dignity as long as it is voluntary. Acts Chapters 2 and 5 are a profoundly anti-state passage, for they deny revenue to the State and places it into the hands of the apostles. Again, none of it is done with force, and all if it is done voluntarily to provide financial assistance to those in need.

\section{The Bible, Force \& Fraud}

As noted in the introduction, the Scripture indicates that God provides honest weights and measures; so, market-clearing prices are just prices. Whoever uses deception, force, or fraud to manipulate them in their favor does not follow God's will. Tampering with the just outcomes of prices is not just a sin or a trespass, but an abomination. If human beings find themselves offended by injustice through corruption, bribery, and 'scale-tipping'...our indignation is no match for that of the Holy God who reserves harsh punishment for those who engage in the use of diverse weights, that is, heavier stones for buying and lighter stones for selling (HERNY, 2009).

God not only hates this type of sin, but He hates this sort of sinner. This is because an abomination is a willful display of disobedience right in God's face, given that both the righteous and the wicked know through their conscience, the balancing of the scales, the reactions of those who are defrauded, and the Word of God itself that such fraud is evil. Given all these testimonies, the sin of fraud in the marketplace becomes all the more heinous, deserving to be labeled an abomination. In Deuteronomy 25, God clarifies that He finds people engaged in this kind of deception to be detestable in His sight (emphasis added). In Psalm 55:23, He tells 
His people to use honest measures, so that He will preserve them, prosper them, and bless them. If they ignore his command, He warns them that he will hate and cast them out of the land, or even have their lives cut short.

This is not mere Old Testament fire and brimstone. In 1 Corinthians 6, Paul makes it abundantly clear that those who are overcome with their greed and who act in the marketplace to swindle, steal, or extort others will never inherit eternal life (POOLE, 1979). Paul, the preacher of grace, clarifies that people who do these things cannot claim to be followers of the LORD Jesus Christ, having no part in His Kingdom. Besides, in 1 Corinthians 5, he instructs believers to have nothing to do with such people, not even to share the most basic forms of hospitality with them. In our day, it would require us to abstain from having coffee with such a person.

We should note that the sanction immediately applied to this type of fraud does not require the interference of any government. The immediate and righteous action is to exclude such a person from social interaction, namely, commercial exchange. Just people on the market must avoid the swindler, refusing to engage in trade with him. Socialists of all stripes would contend that this type of fraud must be met with the 'sword' of government-sponsored fines, imprisonment, or worse because it is created by the market itself, rather than by unscrupulous actors (GUYTON, 2012). However, the Scripture merely calls for peaceful exclusion and potential restitution (as presented in Leviticus 6:1-6) to deter such forms of deceit. Thus, the Scripture does not require any governing authority or State to intervene, even in the case of theft or extortion in the marketplace.

Both the Old and New Testaments use the strongest possible language to condemn fraud in the marketplace. This condemnation is vital to the operation of genuinely free and flourishing markets. On a positive note, when righteousness and integrity are present, human flourishing abounds in and through the marketplace.

\section{The Bible and Unequal Economic Outcomes}

There is no flawless man-made state of utopia: it eventually fails. Socialist utopias are the most frequent examples of such debacles. By contrast, believers in the God of the Scripture await a perfect utopia where peace, justice, joy, and righteousness are complete and perfect. According to the Scripture, that is in the eternal Kingdom of God, and it will be created with the new heaven and new earth. However, as we will see, even in this Kingdom, there is inequality of rewards or status. We know this because the ruler of this Kingdom, this true eternal utopia, told us that this is precisely the case.

In Matthew 25, Jesus tells his disciples in a private conversation on the Mount of Olives the well-known parable of the Talents. The simple and strong lesson of it is that there will be varying rewards in the eternal Kingdom. His disciples already knew this, which is precisely why James and John's mother comes to Jesus just after His triumphal entry into Jerusalem, asking him to give her sons high positions of authority in His Kingdom. She asks for them to be allowed to sit on Jesus' right and left side. He rebukes this sort of request, yet does not deny that these positions of privilege exist. In fact, He acknowledges that they do and that 
it will be up to the Father to place those in positions of authority according to His Father's foreknowledge. Furthermore, Jesus tells his disciples that to reach for the heights of heavenly status, one must serve not as a hired servant, but rather as a fully-owned slave of God! This is the path to wealth, authority, and status in the heavenly Kingdom.

Not long after this, Jesus and His disciples gather again on the Mount of Olives to engage in a conversation about the parable of the Talents. In this parable, Jesus describes himself as the master and His disciples as "doulos" - in other words, as $1^{\text {st }}$-century slaves with great responsibility who are cared for by their masters. The LORD speaks to them of a master who holds astonishing wealth, so much that we could hardly fathom it. We know that this is a wealthy man because he distributes a total of 4.8 million dollars. A single talent is the equivalent of 20 years' wages for a semi-skilled laborer in the United States. The first slave received five talents ( 3 million); the second, two talents (1.2 million); and the third, one (600k). We must observe not only the master's generosity and wealth, but also his initial method of distribution. This is the first clue that there will be unequal outcomes. Jesus acknowledges that different servants have different abilities. This natural inequality exists among all of us. He entrusts us with lesser or greater responsibility, depending on our abilities.

Now, the behaviors of these three slaves are well known. We must remember that Jesus is describing the Eternal Kingdom of God and the visible "kingdom" includes those in this world who call Jesus "master" or "LORD". We know this because the unfaithful servant buried and did nothing productive with the skills, abilities, and fortunes given to him called the master "LORD”, or in the Greek, "Kurios".

Jesus then describes the master's reaction to the varying degrees of faithfulness. In the unfaithful slave case, he is cast out of the eternal Kingdom because he did not know the true LORD, claiming that the master was a 'hard and unjust man.' It is difficult to imagine a person who receives $\$ 600 \mathrm{k}$ in wealth and claims the other giving it was stingy, hard, and unfair.

The rest of the parable and its conclusion are astonishing and demonstrate that wealth inequality exists in the perfect, eternal, just, and joyous Kindgom of Heaven. We see the faithful servants who earned a 100\% return being invited into the joy of fellowship with their master. But what happens to the $\$ 600 \mathrm{k}$ buried by the unfaithful servant. Is it redistributed evenly? Is it returned to the master? It is all given to the one who had a total of \$6 Million! From a theological or even pastoral viewpoint, those who cry foul at God's distribution of rewards simply reassert their pre-existing rejection of the actual Master. They simply echo in our day and age what the unfaithful servant falsely believed about the Lord, that He is cruel, capricious, arbitrary, and unjust. They reject the master's assertion, which Jesus highlights in another parable with a rhetorical question, "Am I not free to use my income as I see fit?" (Matthew 20:1-16).

The ultimate lesson is that there is an unequal distribution of wealth, overseen by the perfect, just, and righteous LORD. Jesus ends with a theological proposition that shatters the modern utopians who claim that equal distribution of income is the essence of economic justice. Jesus says, "For to everyone who has, more will be given, and he will have abundance; but from him who does not have, even what he has will be taken away" (Matthew 25:30). So 
we see that in the perfect, righteous, and just eternal kingdom of God, there is an inequality based on righteous and good works. Even faithful works in our vocations, carried out with love, goodness, and integrity, are eternally rewarded.

Some might say that our characterization of socialists is unfair, because no socialist fights for complete equality of income (SPRAGUE, 1892, p. 2). This is not the lesson of Jesus' teachings. The lesson is that, even after knowing that natural inequality due to varying abilities was real, the unfaithful servant complained against a really good master. Also, note that the servant who gained a 100\% return on two talents never protested the gains of the one with 5 ! Simply put, the fact is that both natural and outcome inequalities bother egalitarians of our day. While the socialists of the past claimed that capitalism caused misery and poverty, only to have their claim dismantled by the facts of history (Sprague, Preface), the present ones claim that capitalism causes inequality, which is allegedly responsible for low life expectancy, infant mortality and more (WATT, 2020). Furthermore, the egalitarian mindset completely ignores the blessings derived from differences in natural ability (RIETNOUR, 2010). Without those, there would be little if any division of labor, innovation, or opportunities for mankind's knowledge to grow.

Concerning the division of labor, some keen insights emerge from the powerful narrative of Genesis and the murder of Abel at the hands of his younger brother, Cain. First, there is a clear articulation of the natural division of labor. Cain was a farmer, and Abel, a hunter. This division of labor confirms the natural differences in talents and skills among even the first humans. Given the land and geographic conditions, they engage in different activities that illustrate not only their varied talents, but also the axiom found in Say's law, that you must produce in order to exchange valued goods, whether with one's own family or with one's God. It also reveals that it is natural for man to trade to meet their subjective values, in such a way as to improve their standard of living. So, both brothers become wealthier by the act of trade.

When they are finally able to discern the voice of God, they both bring sacrifices to Him upon his request. We must note that God has already revealed His will (in economic terms) for what a sacrifice should look like. He specified the proper form of sacrifice when Cain and Abel's parents were cast out of the Garden of Eden: it must be a suitable animal, and it must involve the shedding of that animal's blood. Simply put, God communicated to these two entrepreneurial agents what He wanted, making His wishes clear!

Abel had regard for God and gladly honored the request. It would be fallacious to insist that Cain brought a sacrifice of fruit and vegetables simply because that was all that was available to him. He could have easily traded with his brother Abel, getting the sacrificial animal God had requested. Instead, Cain delivers to God that which He has not asked for. God is also displeased with Cain's hardness of heart. In a profound sense, God is the consumer of the sacrifice. As the story continues, God tells Cain that his disappointment is unwarranted, because God has plenty of favor to dispense. He says in Genesis 4:7, "If you do well, will you not be accepted? "In other words, as the consumer of the sacrifice that both Cain and Abel produce, God is willing and able to bless Cain! He simply has to deliver to God that which He (the consumer) has requested! 
Even Biblical illiterates know where the story goes from here. Rather than adjusting his attitude and actions to serve the consumer better, Cain seeks to remain pleasing to himself. He makes no adjustments to his attitude, production, or pattern of trade with his brother. Instead of making the necessary adjustments to please the consumer, he refuses to do it. In short, Cain is the embodiment of the failed entrepreneur, who refuses to heed the signals of the consumer.

Of course, this is not his only fault. Upon this failure, Cain not only becomes angry with God for not bending to his production preferences, but also adopts the posture of envy, bitterness, resentment. As these attitudes grow in Cain's heart, God mercifully warns him of the dangers of this posture, telling him that sin is waiting at your door like a lion who is ready to pounce and devour. Nonetheless, Cain refuses to heed this warning: overwhelmed by his passions, he plans to destroy not God, but his brother. Why? Is it not because Abel possesses God's (the consumer's) favor, and Cain does not? Is it not because Abel reaped the profit of God's pleasure, and Cain did not? What is Cain's solution to this disparity of outcomes, to this unequal distribution of God's favor, to the fact that Abel possesses divine profit that Cain desires?

Cain's solution is to try to steal God's favor rather than obtain it legitimately. This error reveals that he thinks that God lied on several fronts. First, Cain believes that God has a limited amount of favor to dispense. In other words, he believes that dealing with God is a zero-sum game. By this fallacious thinking, Cain believes that, because Abel "won," Cain necessarily lost. He deliberately disregards what God has already said about His ability to grant his favor in exchange for Cain's potential faithfulness. This fallacy is implicit in all socialist dogmas, especially the narratives that pine away over inequality, naively insisting that when one person becomes wealthy, someone else (or everyone else) necessarily became poorer (CARTER, 2020). Instead, Cain demonstrates the central error of every redistributionist who believes that everyone else loses when one person wins, by resolving to kill. Since Cain's ultimate resentment is against the consumer, God, and while he knows that he can not kill Him, the next best choice is to kill the one who holds the profits he desires.

To put it plainly, the socialists of the $20^{\text {th }}$ century not only reject the notion that men are made in God's image (demonstrated in their materialist doctrines), but sought to and succeeded in murdering millions of image-bearers. And just as Abel's blood cried out from the ground, so too did the blood of millions of Russians, Ukrainians, Romanians, Jews, Cambodians, Vietnamese, Germans, Poles, and countless others by the modern-day spirit of Cain. That envious spirit did not merely appear out of the natural disparities or material conditions of the Industrial Revolution. According to the Bible, it appeared in the first man born on earth.

Instead, imagine that the story had gone differently. Imagine that, by seeing that Abel was blessed, Cain rejoiced and celebrated with him, believing that God's favor was unlimited to the faithful, quickly trading again with Abel some fruit and vegetables for a lamb. Imagine that Cain decided that, to be profitable and blessed, all he had to do was deliver what the consumer of the sacrifice had asked for. Imagine that he changed course willingly, behaving 
like a wise entrepreneur who brings profit and blessing to himself by pleasing others, in this case, his Creator.

This entrepreneur's potential to correctly forecast what the consumer wants and reap profits from it is natural and prescribed by the Scripture. The school of thought that best articulates this wonderful, fruitful, peaceful process is the Austrian school. Therefore, it is no wonder that Austrians have pragmatic, reasonable, and moral reasons to rejoice when entrepreneurs do well.

\section{Conclusion}

Ludwig von Mises clearly articulated a pragmatic and (in his words) utilitarian argument for free exchange. His student, Murray Rothbard, felt that natural law was what led us to understand that voluntary exchange is the proper method of social interaction. In this brief article, we added to the Austro-Libertarian defense of voluntary exchange by demonstrating from key Biblical passages that there is a divine moral law that also points humanity towards the righteousness and justice of free and voluntary trade, free from manipulation, force, or fraud.

It is imperative to secure this kind of argumentation, as the proponents of "Christian socialism" claim that the Scripture defines and supports their position. On the one hand, they ignore its clarion call to productivity and free enterprise. On the other, they misinterpret a small number of Biblical passages that demolish their position. Austro-Libertarians would do well to secure the moral case for free markets not only through the pragmatic and natural law ethical approaches, becoming well-versed in the Biblical case to contest the errors of the "Christian socialists".

\section{References}

BENGEL, J.A. Gnomon of the New Testament. Philadelphia: Smith, English, and Company, 1985.

CARTER, H. W. Christianity and Inequality in the Modern United States. In: AKRAM, T.; RASHID, S. (eds). Faith, Finance, and Economy. Cham: Palgrave Macmillan, 2020.

LAURENCE, Gronlund. Why I Am a Socialist. Twentieth Century, v. 4, n. 19, 1890.

GUYTON, Morgan. Why Christians Shouldn't Be Offended by So-Called Socialism. Available: https://www. redletterchristians.org/why-christians-shouldnt-be-offended-by-so-called-socialism/. Accessed: Aug 102020.

HENRY, Matthew. Matthew Henry's Commentary on the Whole Bible: New Modern Edition. Massachusetts: Hendrickson Publishers, 2009.

KEIL, C.F.; DELITZSCH, F. Commentary on the Old Testament. Michigan: Eerdman's Press, 1982.

LEONARD, Thomas C. Illiberal Reformers: Race, Eugenics, and American Economics in the Progressive Era. Princeton: Princeton University Press, 2016.

MACARTHUR, John. The MacArthur New Testament Commentary: Acts 1-12. Illinois: Moody Publishing, 1994 
MISES, Ludwig. Human Action. Auburn: Ludwig von Mises Institute, 2008.

POOLE, Matthew. A Commentary on the Holy Bible. Pennsylvania: Banner of Truth Publishing, 1979.

RITENOUR, Shawn. Foundations of Economics: A Christian View. Oregon: Wipf \& Stock, 2010.

ROTHBARD, Murray. Man, Economy, and State with Power and Market. The Scholar's Second Edition. Auburn: Ludwig von Mises Institute, 2009.

SIRICO, Robert. Defending the Free Market: The Moral Case for a Free Economy. Regenery Publishing: Washington, D.C, 2012.

SOWELL, Thomas. Say's Law: An Historical Analysis. Princeton, New Jersey: Princeton Legacy Library Publishing, 1972.

SPRAGUE, F. M. Socialism from Genesis to Revelation. Boston: Lee \& Shepherd Publishing, 1982.

ICS. Institute for Christian Socialism Homepage. Available: https://christiansocialism.com/christian-socialismstatement/. Accessed: Aug 112020.

WATTS, Craig M. A Critique of 'Five Reasons Socialism is Not Christian. Available: https://www. redletterchristians.org/a-critique-of-five-reasons-socialism-is-not-christian/. Accessed: Aug 102020.

ReCEIVED: August 11TH, 2021.

APPROVED: OCTOBER 21TH, 2021. 